\title{
Microbiological safety of cooked vended foods in an urban informal market: A case study of Mbare Msika, Harare, Zimbabwe
}

\author{
Raphael Kwiri, Clive Winini, Jeritah Tongonya, Wishmore Gwala, Enock Mpofu, Felix Mujuru, \\ Shannon T. Gwala, Lydia Makarichi, Perkins Muredzi*
}

Food Processing Technology Department, Harare Institute of Technology, Ganges Rd, Belvedere, Box BE 277, Harare, Zimbabwe

\section{Email address:}

rkwiri@hit.ac.zw (R. Kwiri), cwinini@hit.ac.zw (C. Winini), jtongonya@hit.ac.zw (J. Tongonya),wgwala@hit.ac.zw (W. Gwala), empofu@hit.ac.zw (E. Mpofu), fmujuru@hit.ac.zw (F. Mujuru), sgwala@hit.ac.zw (S. T. Gwala), lmakarichi@hit.ac.zw (L. Makarichi), pmuredzi@hit.ac.zw (P. Muredzi)

\section{To cite this article:}

Raphael Kwiri, Clive Winini, Jeritah Tongonya, Wishmore Gwala, Enock Mpofu, Felix Mujuru, Shannon T. Gwala, Lydia Makarichi, Perkins Muredzi. Microbiological Safety of Cooked Vended Foods in an Urban Informal Market: A Case Study of Mbare Msika, Harare, Zimbabwe. International Journal of Nutrition and Food Sciences. Vol. 3, No. 3, 2014, pp. 216-221. doi: 10.11648/j.ijnfs.20140303.24

\begin{abstract}
The study presents an investigation of the microbiological safety of cooked vended foods in an urban informal market in Harare, Zimbabwe. Analyses were performed on 200 samples of mostly vended ready to eat foodstuffs (comprising chicken and beef stew, egg rolls, doughnuts and boiled mealie cobs) between the month of October and November 2012. Samples were analyzed against different types of indicator micro-organisms namely total aerobics, coliforms and Escherichia coli and pathogens (Salmonella spp. and Staphylococcus aureus). Significantly, early morning samples were less contaminated than afternoon samples $(\mathrm{p}<0.05)$. No Salmonella spp. was detected in any of the foodstuffs analysed, though $S$. aureus and E.coli were present (respectively ranges from 3-62x102 cfu/g and 6-49x101 cfu/g). Respectively, nearly 85.5\% and $53 \%$ of the samples were highly contaminated with $S$. aureus and E. coli. Correspondingly, total aerobic plate count ranged from $11-172 \times 103 \mathrm{cfu} / \mathrm{g}$, while coliform count ranged from 8-85 x102 cfu/g. Subsequently, the study showed that informally vended foods might contain pathogenic microorganisms which signify a risk for human health. The importance of adequate measures to guarantee food safety was underscored.
\end{abstract}

Keywords: Indicator Microorganisms, Pathogens, Street Vended Foods, Contamination, Food Safety

\section{Introduction}

According to WHO [32], street-vended foods refers to an assortment of foods and beverages prepared and/or sold in streets and other public places. These foods are either consumed instantly or later without further processing or preparation. Accordingly, this definition embraces fresh fruits and vegetables which are sold outside authorized market areas for immediate consumption. Street vended foods sold through the informal market institute a rapidly growing industry in many developing countries including Zimbabwe. This has been on the rise, due to economic decline, population growth, rapid urbanization, high unemployment and HIV/AIDS pandemic [32], [4]. Respectively, urbanization and population growth, are expected to continue increasing into twenty first century, hence a proliferation in street vended foods. Particularly, in
Zimbabwe street foods are readily available, inexpensive, and nutritionally balanced and also provide a source of income for the vendors [11], [32],[12], [31].

Street food vending plays an important role in Zimbabwe as it provides a wide variety of foods that are relatively cheap, easily accessible and convenient to number of urban inhabitants. Consequently, the street food business is really stimulated by the rapid thriving informal sector which resulted in mushrooming of numerous street food vending sites which are unauthorised. This is coupled with strong business opportunities offered by the sector, especially considering the current emerging entrepreneurial business in Zimbabwe. However, several authors noted that food borne illnesses of microbial origin are a major health problem associated with street vended foods [34],[1],[5], [26]. Street foods are frequently associated with diarrhoeal diseases due to circumstance surrounding their preparation and handling 
which is marked by poor and unhygienic practices [10], [23],[34],[7]. This is due to the fact that, most vendors are often poorly educated, unlicensed and lack training in basic food safety practices concerning raw material acquisition, food preparation, storage, handling, inadequate facilities and final delivery to the consumer [10], [7], [28].

In line with WHO [32], food handling personnel are key in ensuring food safety throughout the food production chain and during storage. Consistent with WHO [32] report, street foods displayed on open yards due to inadequate facilities can easily be contaminated by dust, insects from nearby garbage, hands of intending buyers and rains. Food vendors usually make use of simple facilities like wheel barrows, trays, mats, tables and make-shift stalls, thus further increasing the risk of food contamination. In most cases, most vending sites do not have running water to such an extent that, hand and dish washing are usually done in plastic containers, and sometimes without soap. In addition, potential health risks may originate from use of already contaminated raw materials for example, vegetables which might be possibly contaminated from faeces (manure, both of human and animal origin) and water (used during irrigation and cleaning) [9], [21]. Significantly, pathogens may invade the interior surfaces of the food during preparation processes like peeling, slicing, trimming, packaging, storing and serving [6] . Practices used during food preparation such as handling, cleaning, sorting and grading, packaging, storing and wrapping in low grade plastics are some of the critical factors that increase the risk of inadequate food safety. Rapid proliferation of the street food business has led to the growing concern for food safety. The consumption of these street foods potentially increases the risk of food borne diseases caused by a wide variety of pathogens which include E.coli, Salmonella typhi, Pseudomonas spp., S.aureus [19], [17] .Above all, the responsibility of the street food business is not only to provide nutritious food to the public but also to ensure its microbiological safety and wholesomeness [27] . Again, if a society is to derive full benefits of street vended foods with minimal health risk of food borne disease, government intervention is of paramount importance despite the context of the prevailing local environments. Therefore, the study was undertaken to investigate and develop an understanding of the microbiological safety levels associated with street vended foods at Mbare-Msika-Harare with particular reference to measures that might be identified and put in place to guarantee adequate food safety.

\section{Methodology}

\subsection{Study area Selection}

The study area chosen is the biggest national bus terminus in a metropolitan centre in Zimbabwe, the main commodities national market and an entry point of agricultural produce into the national and regional markets. Mbare-Msika has a large patronage by venders, shoppers, hawkers, and is near the biggest Small and Medium Enterprises (SMEs) industrial area (Siya so). Consequently, traders give results to congested toilet facilities, significant rise of dust from surfaces into air, numerous refuse dumps in and around the market.

\subsection{Chemicals, Media, Reagents and Ancillary Equipment}

Chemicals, media and reagents used were of analytical grade purchased by university food laboratory from Merck Ltd, and Oxoid Ltd, United Kingdom. Ancillary equipment used was made up of well calibrated units namely incubators, thermometers all purchased by the university food laboratory from Incotherm Ltd and Merck Ltd, United Kingdom.

\subsection{Selection of Samples}

Five most vended ready to eat foodstuffs namely, chicken and beef stew, egg rolls, doughnuts and boiled mealie cobs were selected for microbiological analysis and randomly purchased from vendors. Approximately, one vending portion of each selected sample was collected and immediately stored in cooler boxes between $1-4^{\circ} \mathrm{C}$ and transported to the laboratory within 20 minutes of sampling. All samples were examined within 36 hours of sampling and stored between $0-4^{\circ} \mathrm{C}$ prior analyses.

\subsection{Sample Analysis}

For microbiological analysis $10 \mathrm{~g}$ of food samples namely boiled mealie cobs, doughnuts, egg rolls, beef and chicken stews were individually blended in sterile blenders and homogenized in $90 \mathrm{ml}$ buffered peptone water. Thereafter, the food sample homogenates underwent serial dilutions of 10-2, 10-3, 10-4, and10-5 depending on the sampled food items, tests carried out, and the suspected bacterial load. 0.1 $\mathrm{ml}$ aliquots from the resultant dilutions were inoculated in triplicate plates using the pour plate and spread plate techniques. Plate Count Agar (PCA) (Oxoid Ltd, United Kingdom) was used for total aerobic counts (TAC) and was done in conformity with Association of Official Analytical Chemists (Association Official Analytical Chemists, 1990, Maturin and Peeler, 2001). Total coliform count (TCC) and E. coli were done on Violet Red Bile Agar (VRBA) (Oxoid Ltd, United Kingdom) and E. coli colonies were distinguished among the coliform colonies on VRBA by their increased bluish fluorescence around colonies under long wave UV light $(366 \mathrm{~nm})$ on adding $100 \mu \mathrm{g}$ of 4-methyl-umbelliferyl- $\beta$-D-glucuronide (MUG) (Oxoid, Ltd United Kingdom) per $\mathrm{ml}$ in the VRBA overlay. S.aureus enumeration was done as per Bacteriological Analytical Manual (BAM) [8], where Baird Parker Agar (Oxoid Ltd, United Kingdom) was used. The inoculum was equitably distributed to triplicate plates as follows; $0.4 \mathrm{ml}, 0.3 \mathrm{ml}$, and $0.3 \mathrm{ml}$. The plates were incubated at $35^{\circ} \mathrm{C}$ for between $24-30$ hours. Presumptive S. aureus colonies were identified by their distinct morphological properties i.e. dark grey and black convex colonies surrounded by clear zones. The method used for detecting Salmonella spp. was as per the 
BAM (Andrews et al., 2011). Pre-enrichment was done in $1 \%$ peptone water, incubated at $35^{\circ} \mathrm{C}$ for between $18-28$ hours. The selective enrichment cultures were streaked onto Bismuth Sulphur (BS) and Brilliant Green Sulphur (BGS) (Merck Ltd, U.K.) and incubated at $35^{\circ} \mathrm{C}$ for 24 hours to obtain isolate colonies (pink to fuchsia colonies surrounded by red medium on BGS agar, and appearing as black colonies on BS agar with or without a metallic sheen. No growth of Salmonella spp. was detected.

\subsection{Data Analysis}

Statistical analyses were accomplished using Statistical Package for Social Sciences (SPSS), version 10 and Microsoft Excel 2010 software. Statistical significance was set at $p<0.05$. The significance of any perceived differences was determined by analysis of independent samples. The data were also analysed using One Way ANOVA to determine statistical difference of microbial loads between all samples under study.

\section{Results}

Table 1. Microbial counts from sampled foods

\begin{tabular}{|c|c|c|c|c|c|c|c|c|c|}
\hline Food item & $\begin{array}{l}\text { Total Aerobic } \\
\text { count }\end{array}$ & $\begin{array}{l}\text { Total Coliform } \\
\text { count }\end{array}$ & E.coli cou & & S. aureus & & Salmonell & & \\
\hline samples & Morning & Afternoon & Morning & Afternoon & Morning & Afternoon & Morning & Afternoon & \\
\hline \multicolumn{10}{|c|}{ Doughnuts $(n=20)$} \\
\hline Range & $36-52$ & $82-146$ & $31-40$ & $47-67$ & $16-32$ & $27-36$ & $26-34$ & $33-53$ & ND \\
\hline Mean & 45.55 & 113.1 & 35.6 & 60.16 & 23.11 & 31.7 & 28.44 & 45.9 & ND \\
\hline$* \mathrm{~N}$ & $0(0)$ & $0(0)$ & $0(0)$ & $0(0)$ & $20(100)$ & $20(100)$ & $20(100)$ & $20(100)$ & ND \\
\hline \multicolumn{10}{|c|}{ Egg rolls $(n=20)$} \\
\hline Range & $30-60$ & $98-172$ & $27-39$ & $27-70$ & $6-12$ & $22-49$ & $22-32$ & $41-57$ & ND \\
\hline Mean & 49 & 136.55 & 33.35 & 56.85 & 8.6 & 32.7 & 25.95 & 48.7 & ND \\
\hline$* \mathrm{~N}$ & $0(0)$ & $0(0)$ & $0(0)$ & $0(0)$ & $6(30)$ & $20(100)$ & $20(100)$ & $20(100)$ & ND \\
\hline \multicolumn{10}{|c|}{ Boiled mealie cobs $(n=20)$} \\
\hline Range & $11-29$ & $18-52$ & $8-16$ & $26-40$ & 0 & 0 & $3-10$ & $4-18$ & ND \\
\hline Mean & 21.1 & 37.74 & 11.8 & 32.8 & 0 & 0 & 6.45 & 17.11 & ND \\
\hline$* \mathrm{~N}$ & $0(0)$ & $0(0)$ & $0(0)$ & $0(0)$ & $0(0)$ & $0(0)$ & $1(5)$ & $14(70)$ & ND \\
\hline \multicolumn{10}{|c|}{ Beef stew $(n=20)$} \\
\hline Range & $38-66$ & $55-70$ & $22-36$ & $34-75$ & 0 & 0 & $16-40$ & $36-32$ & ND \\
\hline Mean & 53.89 & 62.42 & 29.3 & 49.58 & 0 & 0 & 28.3 & 44.58 & ND \\
\hline$* \mathrm{~N}$ & $0(0)$ & $0(0)$ & $0(0)$ & $0(0)$ & $0(0)$ & $0(0)$ & $20(100)$ & $19(95)$ & ND \\
\hline \multicolumn{10}{|c|}{ Chicken stew $(n=20)$} \\
\hline Range & $21-40$ & $36-56$ & $18-28$ & $31-47$ & $13-34$ & $14-41$ & $13-31$ & $15-53$ & ND \\
\hline Mean & 31.4 & 48.15 & 3.52 & 39.32 & 21.7 & 32.42 & 20.05 & 39.79 & ND \\
\hline$* \mathrm{~N}$ & $0(0)$ & $0(0)$ & $0(0)$ & $0(0)$ & $20(100)$ & $20(100)$ & $20(100)$ & $17(85)$ & ND \\
\hline \multicolumn{10}{|c|}{ Total $(n=200)$} \\
\hline Range & $11-66$ & $18-172$ & $8-40$ & $31-75$ & $6-34$ & $14-49$ & $13-40$ & $4-57$ & ND \\
\hline Mean & 40.19 & 79.6 & 22.71 & 47.74 & 10.68 & 14.48 & 21.84 & 39.22 & ND \\
\hline$* \mathrm{~N}$ & $0(0)$ & $0(0)$ & $0(0)$ & $0(0)$ & $46(46)$ & $60(60)$ & $81(81)$ & $90(90)$ & ND \\
\hline
\end{tabular}

Colony counts were converted to $\mathrm{CFU} / \mathrm{g}$

*N - Number of samples above acceptable limits; percentages (\%)

ND- Not Detected

Microbiological quality of selected food items sold in Mbare-Musika were profiled on the basis of total aerobic plate count (TAC), total coliform count (TCC), E.coli, S.aureus and Salmonella spp. is shown in Table 1. Significantly, afternoon sample had higher microbial load than morning samples $(\mathrm{p}<0.05)$. Table I also revealed that, there is a difference in microbial loads between all samples analysed $(\mathrm{p}<0.05)$. Respectively, in the morning microbial loads were up to $66 \mathrm{cfu} / \mathrm{g}$ for TAC (beef stew), $40 \mathrm{cfu} / \mathrm{g}$ TCC (doughnuts), $34 \mathrm{cfu} / \mathrm{g}$ E. coli (chicken stew), $40 \mathrm{cfu} / \mathrm{g}$ S. aureus (beef stew), while afternoon samples had up to $172 \mathrm{cfu} / \mathrm{g}$ for TAC (egg rolls), $85 \mathrm{cfu} / \mathrm{g}$ TCC (beef stew), 49 cfu/g E. coli (egg rolls), $57 \mathrm{cfu} / \mathrm{g}$ S. aureus (egg rolls). 53\% $(106 / 200)$ of the total sampled food items were E. coli contaminated. All chicken stews and doughnuts samples $(80 / 80 ; 100 \%)$ for both morning and afternoon hours were contaminated. Around (26/40; 65\%) of egg roll samples for morning and afternoon samples were also contaminated. No E. coli was detected in beef stew and boiled mealie cobs for both morning and afternoon samples. All food items tested were $S$. aureus contaminated $(171 / 200 ; 85.5 \%)$ for both morning and afternoon samples, though the boiled mealie cobs were the least $(15 / 40 ; 37.5 \%)$. Salmonella spp. was not detected in all food items sampled.

\section{Discussion}

Cooked vended foods are classified as street foods according to the definition by WHO [32] . Largely, the study noted that, food vendor's hygiene levels were very low combined with poor sanitary environments. Contrary to the above circumstance, results shown in Table 1 are in line with Gilbert et.al, [18] guidelines. Accordingly, the microbiological quality (cfu/g) based on TAC and TCC for 
all selected food items were within acceptable and satisfactory levels[18]. Equally, this was for both morning and afternoon samples. According to Gilbert et.al [18] , TAC and TCC of $<10^{4} \mathrm{cfu} / \mathrm{g}$ is satisfactory, $10^{4}-<10^{5}$ is acceptable and $<100 \mathrm{cfu} / \mathrm{g}$ is satisfactory and $100-<10^{4}$ is acceptable respectively, otherwise it will be unsatisfactory. Both TAC and TCC were respectively ranging from $8-175 \times 10^{2}$ and $8-85 \times 10^{2} \mathrm{cfu} / \mathrm{g}$ ), which were within acceptable ranges for both morning and afternoon samples [18]. TAC and particularly coliforms are indicator organisms (i.e. for hygiene and sanitary conditions) and as such their presence in ready-to-eat foods signifies possible danger [29]. TCC low levels detected in the foods analysed signify good hygiene practices and handling practices. Generally, there was a statistical significant increase in microbial population at $p<0.05$ from morning to afternoon sample. This is an indication of poor handling practices due to holding temperature abuse [29]. Upon observation, street food vendors were keeping their food at ambient temperatures which also progressively increases towards afternoon as compared to morning hours. In accordance with Health Canada, [20] ); Anon [4] ; WHO [32] food should be kept at temperatures below $8^{\circ} \mathrm{C}$ and above $63^{\circ} \mathrm{C}$ otherwise microorganisms will proliferate. FAO/WHO [15] stresses that, improper warm-holding of cooked foods supports growth of microorganisms. In addition, the operating environment was supportive to microbial growth, hence contributed to an increased microbial load in afternoon samples. Furthermore, conditions conducive to microbial contamination (i.e. dusty) could also have contributed to higher afternoon bacterial counts. In agreement with FAO/WHO [15], most vending sites were inappropriately located near overflowing refuse bins sites, and dirty ablution facilities where flies and insects can easily multiply and later cross contaminate food and its preparation stages. Some vending sites were located near roads and pavements where it was dusty. According to a hazard analysis of street foods done by various authors [30], [7], [11], [13], conditions under which some street vendors operate are conveyed to be incompatible for the preparation and selling of food.

No E. coli was detected in beef stew and mealie cobs for both morning and afternoon samples. This could be attributed to the method of preparation for both foods, which involves cooking at temperature above $70^{\circ} \mathrm{C}$ (WHO,[32] ) for at least an hour, which destroys E. coli. The absence of E.coli in mealie cobs could also be due to the protective covering of the boiled mealie cobs natural sheaths which keep away microbiological contaminants despite the poor handling practices during sale.

On the other hand, E. coli was found at unsatisfactory levels in all chicken stew and doughnuts samples (20/20:100\%) for both morning and afternoon hours. In doughnuts $E$. Coli counts ranged between $16-32 \times 10^{1} \mathrm{cfu} / \mathrm{g}$ (morning) and $27-36 \times 10^{1} \mathrm{cfu} / \mathrm{g}$ (afternoon), while for chicken stew were $13-34 \times 10^{1} \mathrm{cfu} / \mathrm{g}$ (morning) and $14-41 \times 10^{1} \mathrm{cfu} / \mathrm{g}$ (afternoon). In doughnuts this could be attributed to multiple bare hand contact with the food item involved during selling and poor packaging. Some doughnuts are supplied to vendors by SME bakers in bulk unsealed low density polyethylene bags where different intending buyers get chance to select their choice by their bare hands which are sometimes dirty. This is supported by WHO [32], where intending buyers were considered as potential source of street food contamination as they use their dirty and already contaminated hands to choose their purchase. In addition, some prepare their merchandise in unknown environs under unknown hygiene conditions. Yeboah- Manu [36] suggests that, the presence of E. coli in food types is an indication of faecal contamination probably at one stage of preparation or from the materials used. Chicken sold by the street vendors is generally purchased from clandestine dealers who slaughter these chickens at their backyards, with unhygienic practises contributing to high levels of E.coli contamination possibly from the chicken intestines. WHO [32] discourages purchase of raw material from such suppliers since they contribute significantly to upstream contamination. In such instances, there is need to ensure adequate cooking in order guarantee food safety [22], [20].

Around $(6 / 20 ; 30 \%)$ of egg roll samples for morning and $(20 / 20 ; 100 \%)$ for afternoon samples were unacceptably contaminated with E.coli. Statistically, there was a significant difference $(p<0.05)$ in E.coli loads for morning and afternoon samples depicting poor handling practices (FAO/WHO, [15] ). Egg-roll preparation is done manually, hence excessive handling which might later contaminate the product. Again, this indicates poor holding temperatures and further contamination from intending buyers, surroundings and vendors (i.e. not wearing head gears and aprons, and sometimes dirty, and odorous and concurrently handle money and food with open palm). The egg-rolls are held at ambient temperatures which encourage microbiological growth, where temperatures between $8-63^{\circ} \mathrm{C}$ are not encouraged (Anonymous, 2004).

All food items tested for $S$. aureus for both morning and afternoon samples were contaminated with levels above $10^{2}$ which are unsatisfactory according to Gilbert et. al, (2000). There was a significant $(p<0.05)$ increase in microbial load from morning to afternoon hours. This could be attributed to holding temperatures and increased afternoon temperature which favour microbial growth in the food and excessive handling (Anonymous, [4] ). S. aureus contamination might have resulted from human's respiratory passages, skin and superficial wounds which are common sources of $S$. aureus [16]. Consistent with Burt et. al, (2003), most vendors did not put on protective clothing during operation (e.g. head gears, aprons and concurrently handle money and food with open palm). The presence of S.aureus should be of outmost concern since it is an enterotoxin producer which can cause gastroenteris [36] . Above all, Salmonella spp. was not detected in all food items sampled. Research by (Gilbert et al., [18] ) ascertains that ready to eat foods should be free from Salmonella spp. 
Adequate hygiene and sanitary standards and appropriate cooking during final preparation warrants absence of these pathogens therefore ensuring food safety. Therefore, absence of Salmonella spp. is an indication of appropriate food preparation though hygiene and sanitation standards were very low based on the contextual environment.

Microbiological safety of street foods require sequential and logical step by step analysis towards reducing the risks of food borne illness by monitoring food preparation steps up to consumption. This is because, most food preparation steps including their environment and handling personnel significantly contribute to the contamination, growth and survival of the microbes responsible for food borne illness [7], [32], [28] . To enable official recognition and control of the street food business as an integral part of the food supply, appropriate legislation need to be in place, incorporated and implemented into existing food regulations. Above all, government commitment has to be drawn on board through the drafting of a food safety policy which also caters for street foods. The policy also acts as a guideline for use by local municipal authorities, analytical labs and food standard authorities [30], [33]. The local authorities, in partnership with other relevant stakeholders then provide appropriate food safety training (including Good Manufacturing Practices (GMP) and Good Hygienic Practices (GHP), for street vendors as research has found that the majority of street vendors lack basic knowledge in this area ([32], [30], [14] . Considerably, specific locations need to be identified and developed into "food centres" or "street food vending sites" that are equipped with adequate infrastructure where street vendors will conduct their operations with improved environmental conditions and essential utility services ([15], [3] . Regulatory aspects through local authorities is required so as license the vendors, hence easing their monitoring and operation . According to FAO, [14], street food vendors might be licensed categorically based on street food health risk, hence this will also ease their monitoring where close supervision is needed to those who are trading high risk product such as animal and animal derived products. Above all, public awareness programs on street food business need not to be over emphasised since food hygiene, safety, preparation and handling practices knowledge is critical to street food vendors so as to avoid preparation and selling of contaminated food.

\section{Conclusion}

In conclusion, the unacceptable contamination levels of most street vended foods with E.coli and S.aureus exposed the potential hazard of street vended foods. Therefore, this study has established that some of the most food items vended on the streets of Mbare-Msika, Harare do not meet required quality and safety levels of ready to eat meals ([18] Again, the study results suggest that, though good hygiene and sanitary practices may prevail during processing and handling of street foods but, that does not guarantee pathogen free food. Consequently, it is of paramount importance to consider microbiological safety and wholesomeness of street foods through development of tailor made GMP and GHP, awareness programs for street food business. Importantly, the government support is needed through provision of complementary legislative framework coupled with provision of adequate infrastructure in specific selected locations, hence formalising street food operations.

\section{References}

[1] Abdussalam, M. \& Kaferstein, F. K. 1993. Safety of street foods. World Health Forum 14: 191 - 194.

[2] Andrews, W. H., Jacobson, A. \& Hammack, T. 2011. Salmonella, Chapter 5, rev. Nov. 2011. In FDA Bacteriological analytical manual, 8th ed., Rev. A. AOAC International, Gaithersburg, MD.

[3] Anonymous. 1997. A Guide to HACCP Systems in the Meat Industry. Ministry of Agriculture, Wellington.

[4] Anonymous. 2004. Improving food safety of informally vended foods in Southern Africa. Coalition partnership in UK, Zambia and Zimbabwe. online $<$ http://www.nri.org/projects/streetfoods/project3.htm>.

[5] Arambulo, P., Almeida, C., Juan, C. \& Albino, J. 1994. Street food vending in Latin America. Bull PAHO 38:344-354.

[6] Aycicek, H., Utku, O. \& Koray, K. 2006. Determination of total aerobic and indicator bacteria on some raw eaten vegetables from wholesalers in Ankara, Turkey.

[7] Barro, N., Bello, A. R., Itsiembou, Y., Savadogo, A., Owattara, C., Nikiema, P., De SC \& Traore, A. S. 2007. Street vended foods Improvement: Contamination Mechanism and Application of food safety objective strategy: Critical Review. Pakistan Journal of Nutrition 6(1): 1-10.

[8] Bennett, R. W. \& Lancette, G. A. 2001. Staphylococcus aureus, Chapter 12, rev. Jan. 2001. In FDA Bacteriological analytical manual, 8th ed., Rev. A. AOAC International, Gaithersburg, MD. .

[9] Beuchat, L. R. 2002. Ecological factors influencing survival and growth of human pathogens on raw fruits and vegetables. Microbes and Infection. Vol 4, 413-423.

[10] Bryan, F. L., Mechanie, S. C., Alvarez, P. \& Paniagua, D. 1988. Critical control points of street-vended foods in the Dominican Republic. Journal of Food Protection. 51,373-383.

[11] Dawson, R. \& Canet, C. 1991. International activities in street foods. Food Control 2:135-139.

[12] Ekanem, E. O. 1998. The street food trade in Africa:Safety and socio-environmental issues. Food Control 9, 211-215.

[13] FAO. 1989. Street foods. A summary of FAO studies and other activities relating to street foods. Rome; FAO.

[14] FAO. 1995. Street foods. Report of an FAO Technical Meeting on Street Foods, Calcutta, India, 6-9 November 1995. 
[15] FAO/WHO. 1984. 'The Role of Food Safety in Health and Development: Report of a Joint FAO/WHO Expert Committee on Food Safety', WHO Technical Report 705, WHO, Geneva.

[16] Feglo, P. \& Sakyi, K. 2012. Bacterial contamination of street vending food in Kumasi, Ghana. Journal of Medical and Biomedical Sciences 1 (1): 1-8.

[17] Ghosh, M., Wahi, S. \& Ganguli, K. M. 2007. Prevalence of enterotoxigenic Staphylococcus aureus and Shigella spp. in some raw street vended Indian foods. International Journal of Environmental Health Research.17(2): 151-6.

[18] Gilbert, R., De-Louvois, J., Donovan, T., Little, C. \& Nye, K. 2000. Guidelines for the microbiological quality of some ready-to-eat foods samples at the point of ne sale. Communicable Disease and Public Health 3:163-167.

[19] Hanoshiro, A., Morita, M., Matte, G. R., Matte, M. H. \& Torres, E. 2004. Microbiological quality of selected foods from a restricted area of Sao Paulo city, Brazil. Food Control 16: 439-444.

[20] Health Canada. 2010. Health Canada www.hc-sc.gc.ca Date Modified: 2010-08-11.

[21] Johannessen, G. S., Loncarevic, S. \& Kruse, H. 2002. Bacteriological analysis of fresh produce in Norway. International Journal of Food Microbiology. 77, 199-204.

[22] Kaferstein, F. \& Abdussalam, M. 1999. Food safety in the 21st entury.Policy and Practice. Bulletin of the World Health Organization, 1999, 77 (4).

[23] King, L., Awumbila, B., Canacoo, E. \& Ofosu-Amaah, S. 2000. An assessment of the safety of street foods in the Ga district of Ghana; implication for the spread of zoososes. Acta tropica 76: 39-43.

[24] Koo, H. L., Zhi-Dong, J., Brown, E., Garcia, C., Huibin, Q. \& DuPont, H. L. 2008. Coliform Contamination of Vegetables Obtained from Popular Restaurants in Guadalajara, Mexico, and Houston, Texas, Journal of Clinical Infectious Diseases; Vol. 47 Issue 2, p218.
[25] Maturin, L. \& Peeler, J. T. 2001. Aerobic Plate Count, Chapter 3, rev. Jan. 2001. In FDA Bacteriological analytical manual, 8th ed., Rev. A. AOAC International, Gaithersburg, MD.

[26] Mensah, P., Yeboah-Manu, D., Owusu-Darko, K. \& Ablordey, A. 2002. Mensah P, Yeboah-Manu D, Owusu-Darko K, Ablordey A (2002). Street foods in Accra, Ghana: How safe are they? Bull. World Health Organisation. 80 (7): 546-554.

[27] Mohapatra, A., Rath, C., Dash, S. \& Mishra, R. 2002. Microbiological evaluation of street foods in Bhubaneshwar. Journal of Food Science Technology, 39 (1):59-61.

[28] Moy, G., Hazzard, A. \& Kaferstein, F. 1997. Improving the safety of street-vended food. World Health Statistic Quarterly. $50(1-2), 124-131$.

[29] Oranusi , U. \& Braide, W. 2012. A study of microbial safety of ready-to-eat foods vended on highways: Onitsha-Owerri, south east Nigeria, International Research Journal of Microbiology, Vol. 3(2), 066-071.

[30] Rane, S. 2011. Street Vended Food in Developing World: Hazard Analyses.

[31] Swanepoel, F. J. J., Hobbs, C., Becker, P. J. \& Ijsselmuiden, C. 1995. The quality of food sold by traders in central Johannesburg and factors associated with contamination . Journal of Comp. Health 6,188-190.

[32] WHO. 1996. Essential safety requirements for street vended foods. Food Safety Unit, Division of Food and Nutrition, WHO/FNU/FOS/96.7.

[33] WHO. 2002a. WHO Global Strategy for Food Safety:Safer Food for Better Health. Food Safety Issues, WHO, Geneva.

[34] WHO. 2002b. WHO Global Strategy for Food Safety:Safer Food for Better Health. Food Safety Issues, WHO, Geneva.

[35] WHO. 2002b. Food safety and foodborne illness. Fact Sheet, No $237,7$.

[36] Yeboah-Manu, D., Kpeli, G., Akyeh, M. \& Bimi, L. 2010. Bacteriological Quality of Ready-to-Eat Foods Sold on and around University of Ghana Campus. Research Journal of Microbiology, 5: 130-136. 